\title{
Synthesized OVA $323-339$ MAP octamers mitigate OVA-induced airway inflammation by regulating Foxp3 T regulatory cells
}

Wen $\mathrm{Su}^{1 \dagger}$, Wenwei Zhong ${ }^{1 \dagger}$, Yanjie Zhang ${ }^{1}$ and Zhenwei Xia ${ }^{1,2^{*}}$

\begin{abstract}
Background: Antigen-specific immunotherapy (SIT) has been widely practiced in treating allergic diseases such as asthma. However, this therapy may induce a series of allergic adverse events during treatment. Peptide immunotherapy (PIT) was explored to overcome these disadvantages. We confirmed that multiple antigen peptides (MAPs) do not cause autoimmune responses, which led to the presumption that MAPs intervention could alleviate allergic airway inflammation without inducing adverse effects.

Results: In this study, synthesized OVA ${ }_{323-339 M A P}$ octamers were subcutaneously injected into ovalbumin (OVA)sensitized and -challenged Balb/c mice to observe its effect on allergic airway inflammation, Th2 immune response, and immune regulating function. It was confirmed that OVA sensitization and challenge led to significant peritracheal inflammatory, cell infiltration, and intensive Th2 response. Treatment of OVA $323-339$ MAP octomers in the airway inflammation mice model increased $\mathrm{CD} 4^{+} \mathrm{CD} 25^{+} \mathrm{Foxp} 3^{+} \mathrm{T}$ regulatory (Treg) cells and their regulatory function in peripheral blood, mediastinal draining lymph nodes, and the spleen. Furthermore, $\mathrm{OVA}_{323-339} \mathrm{MAP}$ increased IL-10 levels in bronchial alveolar lavage fluid (BALF); up-regulated the expression of IL-10, membrane-bound TGF- $\beta 1$, as well as Foxp3 in lung tissues; and up-regulated programmed death-1 (PD-1) and cytotoxic T lymphocyte associated antigen 4 (CTLA-4) on the surface of Treg cells. These results were further correlated with the decreased OVA specific immunoglobulin E (slgE) level and the infiltration of inflammatory cells such as eosinophils and lymphocytes in BALF. However, OVA mentioned effects in the same animal model.
\end{abstract}

Conclusions: Our study indicates that $\mathrm{OVA}_{323-339} \mathrm{MAP}$ had significant therapeutic effects on mice allergic airway inflammation by regulating the balance of Th1/Th2 response through Treg cells in vivo.

Keywords: Allergic airway inflammation, Specific immunotherapy, Multiple antigen peptide

\section{Background}

Bronchial asthma, one of the most common chronic inflammatory diseases, has complex pathogenic mechanisms. As an allergic disease, it is mediated mainly by Th2 immune responses, and is affected by genetic as well as environmental factors. Many approaches for treating this disease are palliative rather than disease modifying. In the past century, antigen-specific immunotherapy (SIT)

\footnotetext{
* Correspondence: xzw63@hotmail.com

${ }^{\dagger}$ Equal contributors

'Department of Pediatrics, Ruijin Hospital Affiliated to Shanghai Jiao Tong University School of Medicine, Shanghai, China

${ }^{2}$ Department of Pediatrics, Ruijin Hospital, Ruijin 2nd Road 197, Shanghai 200025, China
}

(c) 2012 Su et al.; licensee BioMed Central Ltd. This is an Open Access article distributed under the terms of the Creative Commons Attribution License (http://creativecommons.org/licenses/by/2.0), which permits unrestricted use, distribution, and reproduction in any medium, provided the original work is properly cited.

has been widely practiced in treating allergic diseases, and has been a form of disease-modifying treatment, which has been demonstrated to be clinically efficacious in asthma [1,2]. However, the SIT desensitizers commonly used presently are whole allergen preparations that have the potential to induce a series of adverse allergic events that can, at times be fatal [3]. On this basis, many approaches that can reduce the allergenicity of immunotherapy preparations and maintain their immunogenicity are under development. One of these approaches is peptide immunotherapy (PIT), which utilizes synthesized short peptides containing major $\mathrm{T}$ cell epitopes of the allergen. This approach could present allergen-derived $\mathrm{T}$ cell epitopes while 
avoiding the immunoglobulin E (IgE) mediated mast cells or basophils. Synthesized short peptides containing major $\mathrm{T}$ cell epitopes of cat allergen Fel d1, dust mite allergen Der p2, birch pollen allergen Bet v1 and bee venom allergen Api $\mathrm{m} 1$ have been demonstrated to be efficacious in experimental animal models in recent years [4-7].

Clinical studies have also shown that in patients allergic to cats, rhinitis symptom scores, asthma symptom scores, and lung function were all improved markedly after peptide treatment [8-14]. However, some conflicting results were also reported. Janssen et al. [15] found that $\mathrm{OVA}_{323-339}$ peptides containing major $\mathrm{T}$ cell epitopes of ovalbumin (OVA) proteins do not mitigate the effects of airway inflammation, but conversely, aggravate disease in OVA-induced asthmatic mice. The same result has been observed in encephalomyelitis (EAE) mice model. Wegman et al.[16] found that PLP ${ }_{139-151}$ peptide (proteolipid protein) monomers had no effect in improving disease, while synthesized PLP PL-151 $_{139}$ multiple antigen peptide (MAP) octamers successfully inhibited the occurrence of EAE induced by encephalitis pathogenic protein, thus demonstrating that peptide monomers processing can alter their immunological characteristics.

MAPs are dendriform peptides, which can be tetramers or more typically, octamers. Each peptide monomer is independently and covalently linked to a branched central lysine matrix. MAPs can induce high levels of immune response and have been used in vaccine development for a variety of infectious diseases $[17,18]$. In addition, MAPs can also enhance the peptide-specific $\mathrm{T}$ cell response and play a role in the protective immune response [19-22]. Also, Wegman et al.[16] further expanded the scope of MAPs application in studies of autoimmune diseases. There have been no reports of studies concerning the treatment of allergic airway inflammation using MAPs. Therefore, in the present study, eight $\mathrm{OVA}_{323-339}$ short peptides were integrated on a lysine core matrix to constitute $\mathrm{OVA}_{323-339} \mathrm{MAP}$ octamers, which were then subcutaneously injected into OVA-induced allergic airway inflammation mice. The inhibitory effect of $\mathrm{OVA}_{323-339} \mathrm{MAP}$ on airway inflammation and Th2 immune response were observed and compared with $\mathrm{OVA}_{323-339}$ monomers.

Based on the current theories, $\mathrm{T}$ regulatory (Treg) cells proliferation is crucial in maintaining homeostasis. However, existing research on the role of Treg cells in PIT treatment remain controversial [23,24]. In our preliminary study, we found that Treg cells played an important immunoregulatory role in the development and progression of airway inflammation in mice $[25,26]$. Thus, the changes of Treg cells after $\mathrm{OVA}_{323-339}$ MAP octamer treatment were further explored in this study.

\section{Results}

OVA $_{323-339}$ MAP intervention attenuates OVA-induced airway inflammation

Recently, MAPs have been shown to alleviate the severity and block the progress of EAE [16]. This finding emphasizes the potential of MAPs intervention as an effective immunotherapy to treat antigen-specific allergic diseases. Thus, to examine the impact of MAPs on allergic lung disease, we sensitized Balb/c mice with OVA emulsified in $\mathrm{Al}(\mathrm{OH})_{3}$ and induced airway inflammation by intranasal administration of the antigen. As illustrated in Figures 1 and 2 A, OVA priming and activation led to a high inflammation score associated with marked peribronchial leukocyte infiltration, edema, and epithelial damage. Systemic administration of regular OVA $_{323-339}$ peptide before local antigen activation did not alter the severity of the airway inflammation and tissue injury, whereas treatment with $\mathrm{OVA}_{323-339} \mathrm{MAP}$ substantially reduced the inflammatory response in a dose-dependent manner. In addition to the histological evaluation, we assessed airway inflammation by examining total cell counts and eosinophil, neutrophil, lymphocytes and macrophages counts in bronchial alveolar lavage fluid (BALF) of these mice. Compared to the normal control group, OVA sensitization and challenge induced a significant increase of total cells, eosinophils, neutrophils, lymphocytes and macrophages counts, $\mathrm{OVA}_{323-339}$ peptide monomers intervention mildly reduced the total cell count and EOS number. However, a significant decrease in total cell as well as EOS and LYM infiltrates was observed in $\mathrm{OVA}_{323-339} \mathrm{MAP}$ treated mice (Table 1).

Antigen specific immunoglobulin E (sIgE) plays an important role in allergic cell degranulation and hyperresponsiveness. Therefore, we tested whether MAPs intervention altered immunoglobulin production and switching. As shown in Figure 2 B, no OVA-sIgE was detected in the serum of control animals, whereas OVA challenge led to a robust production of IgE that specifically recognizes OVA. Conversely, $\mathrm{OVA}_{323-339} \mathrm{MAP}$ treatment significantly suppressed the level of OVA-sIgE. Interestingly, the mice administered with $\mathrm{OVA}_{323-339} \mathrm{MAP}$ had a substantial elevation of OVA-specific immunoglobulin $G_{1}\left(\operatorname{sIgG}_{1}\right)$ which is the indicator for the success of immunotherapy, compared to the control and $\mathrm{OVA}_{323-339}$ peptide monomers treated groups (Figure $2 \mathrm{C}$ ). This data suggest that $\mathrm{OVA}_{323-339} \mathrm{MAP}$ intervention may mitigate the antigen-specific allergic process and response.

Based on the above results, we further explored how the $\mathrm{OVA}_{323-339} \mathrm{MAP}$ mitigates the airway allergic airway.

\section{$\mathrm{OVA}_{323-339} \mathrm{MAP}$ intervention alters the OVA-induced Th2 response}

It is well documented that OVA-induced airway inflammation in Balb/c mice is mainly mediated by a Th2 

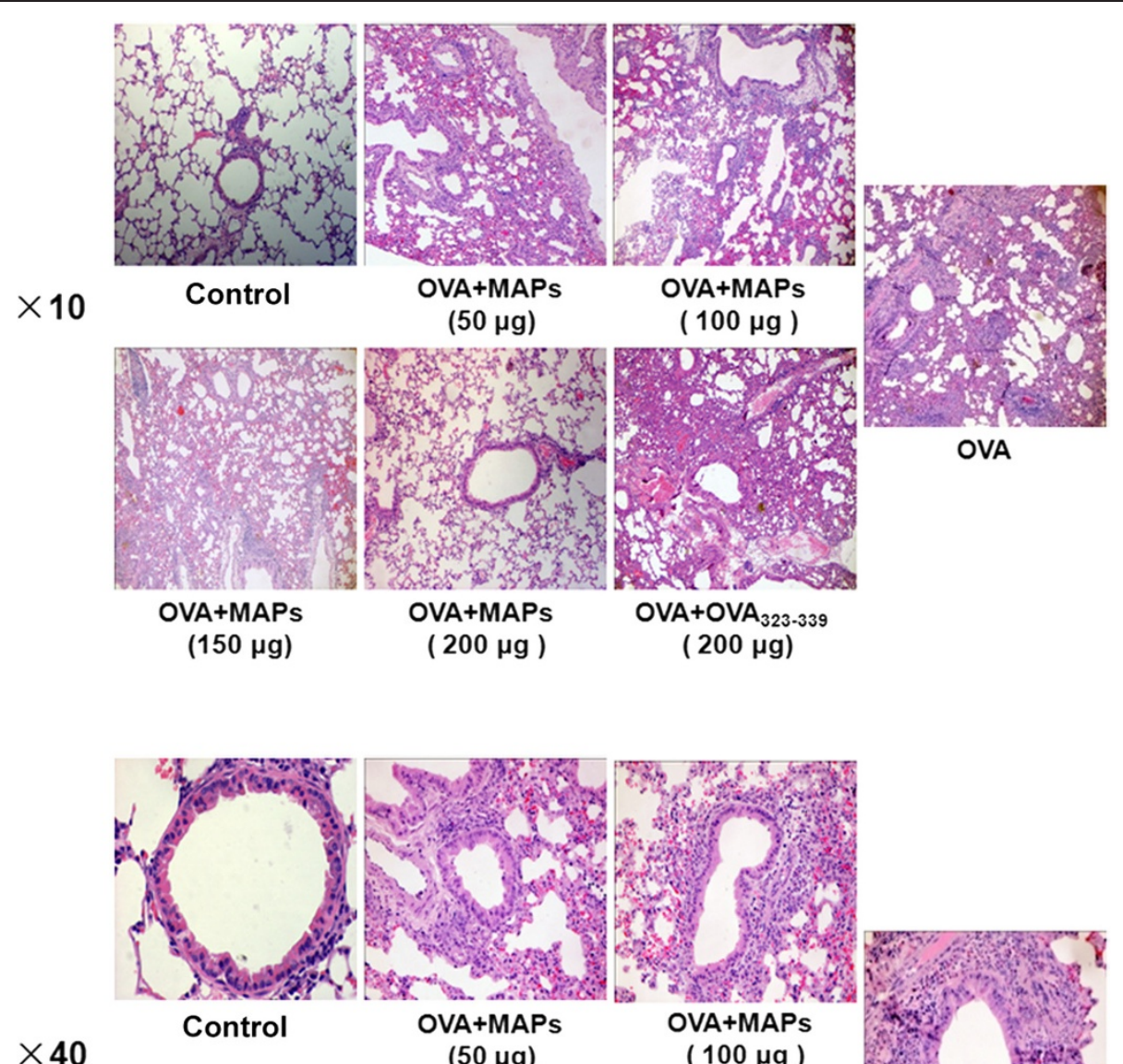

$\times 40$

$(50 \mu \mathrm{g})$

$(100 \mu \mathrm{g})$
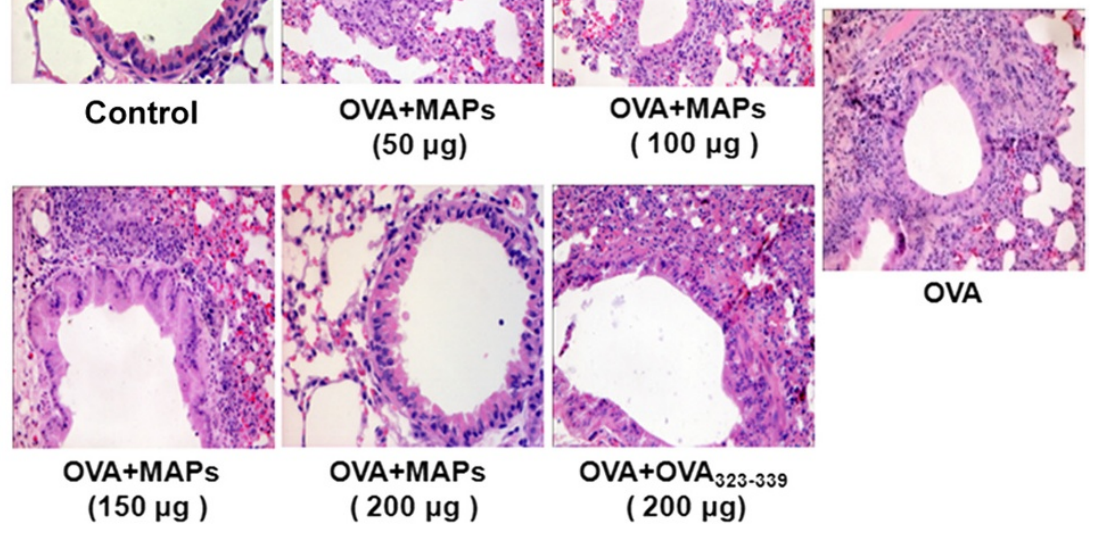

Figure 1 Impact of $\mathrm{OVA}_{323-339}$ and $\mathrm{OVA}_{323-339} \mathrm{MAP}$ intervention on airway inflammation in mice. After OVA sensitization and challenge, typical airway inflammation was observed in Balb/c mice. The airway inflammation was not significantly alleviated by subcutaneous injection of $200 \mu \mathrm{g}$ of $\mathrm{OVA}_{323-339}$ peptide monomers. However, OVA $323-339 \mathrm{MAP}$, containing the equivalent weight of peptides, significantly reduced peritracheal inflammatory cells infiltration and this effect was dose-dependent. Data represent one of three independent experiments.

response. In light of the finding that $\mathrm{OVA}_{323-339} \mathrm{MAP}$ can attenuate allergic airway inflammation, we asked if $\mathrm{OVA}_{323-339}$ MAP treatment alters the OVA-induced Th2 response in the host. To this end, we measured the expression of Th1/Th2-related cytokines (IFN- $\gamma$, IL-4, IL-5 and IL-13) and the ratio of IFN- $\gamma / \mathrm{IL}-4$ in the BALF of these mice. The levels of IL-4, IL-5 and IL-13 were significantly elevated in mice challenged with OVA (Figure $3 \mathrm{~A}, \mathrm{D}, \mathrm{E}$ ), while the ratio of IFN- $\gamma / \mathrm{IL}-4$ decreased significantly (Figure $3 \mathrm{C}$ ). However, $\mathrm{OVA}_{323-339} \mathrm{MAP}$ intervention reduced local Th2 cytokines production and increased the level of IFN- $\gamma$ and the ratio of IFN- $\gamma /$ IL-4 (Figure $3 \mathrm{~A} \sim \mathrm{E}$ ). Furthermore, in order to determine if $\mathrm{OVA}_{323-339}$ MAP treatment influences antigen recall response in mice sensitized with OVA, splenocytes from control and OVA-challenged mice with or without $\mathrm{OVA}_{323-339} \mathrm{MAP}$ intervention were harvested. The IL-4 and IFN- $\gamma$ positive populations were analyzed by flow cytometry (FCM) in CD4 $4^{+} \mathrm{T}$ cells and the amount of IL-4, IL-5, IL-13 and IFN- $\gamma$ in the cell culture media were quantified by ELISA. When the lymphocytes were restimulated with OVA in vitro, $\mathrm{CD}^{+} \mathrm{T}$ cells from OVA-challenged mice exhibited a significantly higher IL-4 production than the control group. In vivo treatment with 

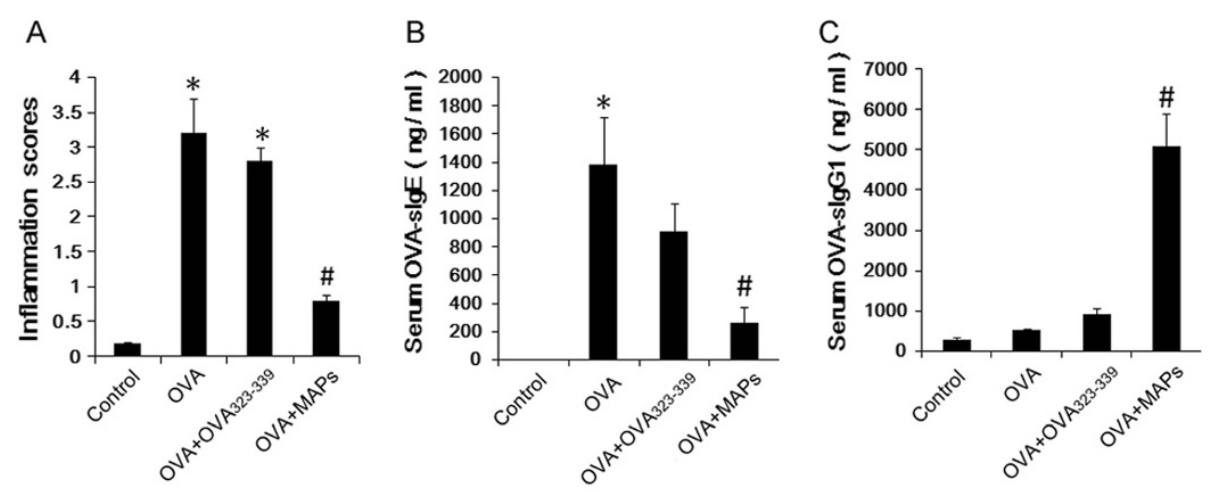

Figure 2 Peribronchila inflammation score and immunoglobulin levels in serum. The peribronchial inflammation score and OVA-slgE levels in OVA group and $\mathrm{OVA}_{323-339}$ group were significantly increased, but they were significantly decreased accompanied by increased OVA-slgG1 after OVA $323-339$ MAP treatment (* compared with the control group, $P<0.05$; \# compared with the OVA ${ }_{323-339}$ group, $P<0.05$ ). Data represent one of three independent experiments.

OVA $_{323-339}$ MAP virtually blocked Th2 cytokines production in response to OVA re-stimulation (Figure $4 \mathrm{~A}, \mathrm{G}$ ). Likewise, ELISA demonstrated that splenocytes from OVA-challenged mice exhibited a significantly higher IL-4, IL-5 and IL-13 response to antigen re-stimulation, while this antigen recall response was diminished in OVA $_{323-339}$ MAP-treated mice (Figure 4 B, E, F). Interestingly, $\mathrm{OVA}_{323-339} \mathrm{MAP}$ intervention caused more IFN- $\gamma$ products while the levels of IFN- $\gamma$ between the control and airway inflammation groups were biologically insignificant (Figure $4 \mathrm{C}$ ). These results suggest that OVA $_{323-339}$ MAP may alter Th2 response in this allergic airway model.

OVA $_{323-339}$ MAP intervention increased the populations of $\mathrm{CD} 4^{+} \mathrm{CD} 25^{+} \mathrm{Foxp}^{+}{ }^{+}$Treg cells, up-regulated the production of IL-10, membrane-bound TGF- $\beta 1$ and Foxp3 in the lung, as well as the surface expression of PD-1 and CTLA-4.

In light of these findings, we evaluated whether $\mathrm{OVA}_{323-339} \mathrm{MAP}$ induces peripheral tolerance as a part of a potential mechanism for mitigating OVA-induced airway inflammation. Treg cells regulate the functions of other $\mathrm{CD} 4^{+} \mathrm{CD} 25^{-}$effector cells and play an important role in balancing Th1/Th2 cell differentiation. Therefore, we observed the alteration of Treg cells. $\mathrm{CD} 4^{+} \mathrm{CD} 25^{+} \mathrm{Foxp} 3^{+}$ Treg cells in peripheral blood, mediastinal draining lymph nodes, and spleen were measured by FCM. In vivo OVA challenge decreased the level of Treg cells in the mice. However, $\mathrm{OVA}_{323-339} \mathrm{MAP}$ increased the population of local and peripheral $\mathrm{CD} 4^{+} \mathrm{CD} 25^{+} \mathrm{Foxp}^{+}{ }^{+}$Treg cells approximately $0.5-1.0$ fold (Figure 5). In addition, we further detected the Foxp3 transcription expression in the lung to observed Treg cells in inflamed local tissue. The result showed that Foxp3 expression in the lung was augmented by MAPs intervention (Figure $3 \mathrm{~J}$ ).

$\mathrm{CD} 4^{+} \mathrm{CD} 25^{+} \mathrm{Foxp}^{+}$Treg cells exert their regulatory effect on immune effector cells by both direct contact and indirect suppression. The indirect suppression is mediated by anti-inflammatory cytokines including IL10 and transforming growth factor (TGF)- $\beta 1$. Thus, we measured IL-10 and TGF- $\beta 1$ levels in BALF and their expression in lung tissue. As shown in Figure $3 \mathrm{~F}$ and I, OVA challenge significantly decreased the level of IL-10 in BALF and lung tissue, but $\mathrm{OVA}_{323-339}$ MAP intervention increased its concentration. Although the level of TGF- $\beta 1$ in BALF was not affected by MAPs (Figure 3 G), the transcription of TGF- $\beta 1$ in lung was significantly decreased in OVA challenge mice when compared to control mice. However, it is important to note that OVA $_{323-339}$ MAP intervention could reverse this change which is consistent with the results shown in our previous publication (Figure $3 \mathrm{H}$ ) [25].

Table 1 Total Cells and Differential Cells Counts in BALF $\left(\times 10^{4}\right)$

\begin{tabular}{lllllc}
\hline & Total cells & Eosinophils & Neutrophils & Lymphocytes & Macrophages \\
\hline Control & $8.91 \pm 1.17$ & $0.00 \pm 0.00$ & $0.05 \pm 0.00$ & $0.19 \pm 0.01$ & $8.37 \pm 1.57$ \\
OVA & $74.64 \pm 12.60 *$ & $9.08 \pm 2.20 *$ & $2.12 \pm 0.52 *$ & $4.51 \pm 1.43 *$ & $58.41 \pm 10.05 *$ \\
OVA + OVA $_{323-339}$ & $63.64 \pm 8.07 \#$ & $4.58 \pm 0.86 \#$ & $1.03 \pm 0.15$ & $3.06 \pm 0.52$ & $55.59 \pm 9.91$ \\
OVA + MAPs & $43.32 \pm 5.64 \S$ & $1.02 \pm 0.16 \S$ & $0.92 \pm 0.16$ & $0.86 \pm 0.11 \S$ & $40.24 \pm 6.29$ \\
\hline
\end{tabular}

${ }^{*} P<0.05$ Compared with Control group.

$\# P<0.05$ Compared with OVA group.

$\S P<0.05$ Compared with OVA + OVA ${ }_{323-339}$ group. 


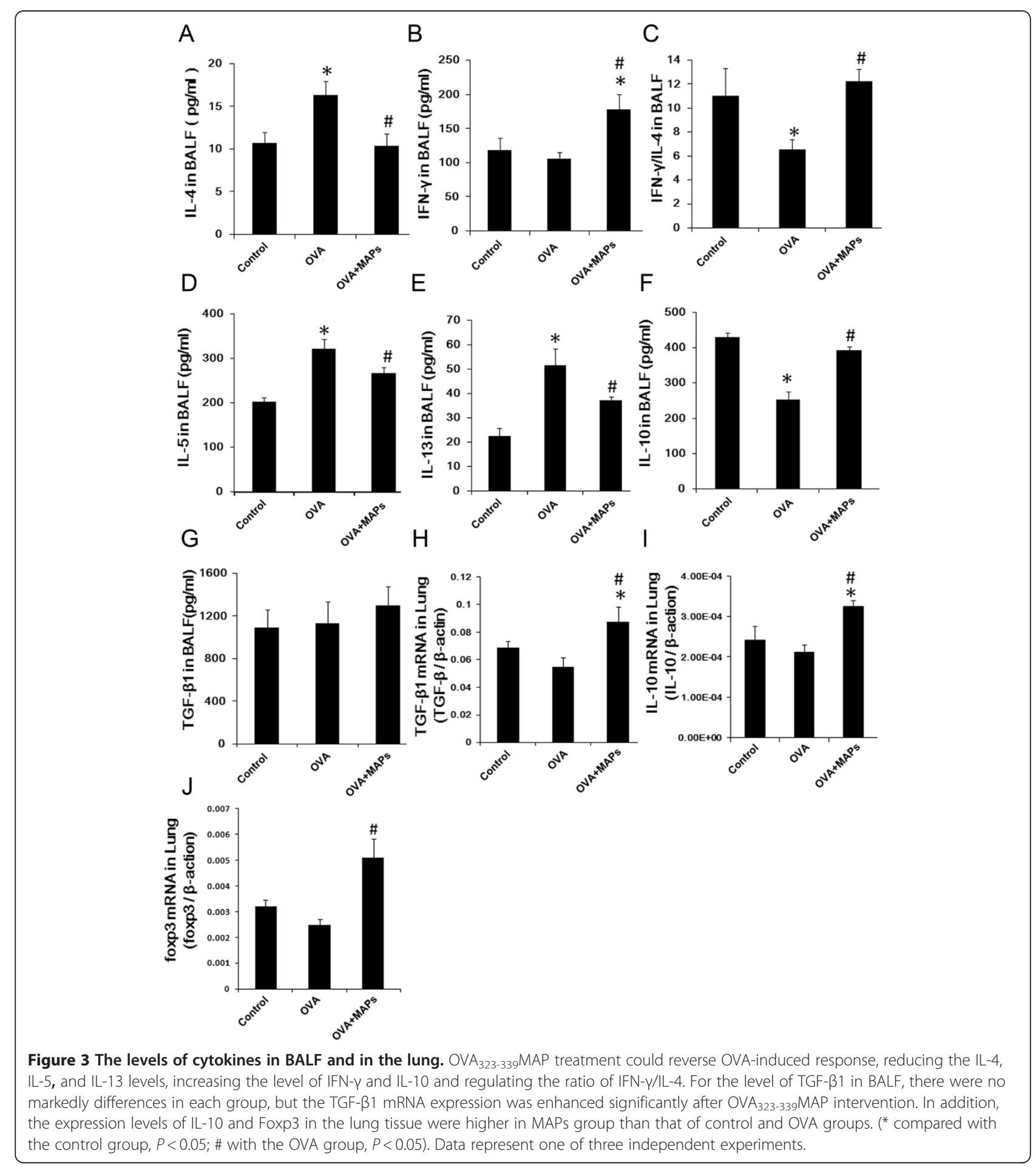

Cell-cell contacting is the other mechanism of Treg function, co-stimulatory molecules such as programmed death (PD)-1 and cytotoxic $\mathrm{T}$ lymphocyte associated antigen (CTLA)-4 contribute to the regulatory function of Treg cells. Therefore, we investigated the expression of PD-1 and CTLA-4 on the surface of Treg cells by FCM. Interestingly, compared to the control mice, OVA challenge elevated the expression of PD-1 mildly, however, the ratio of $\mathrm{PD}-1^{+}$Treg cells increased significantly after treatment with $\mathrm{OVA}_{323-339} \mathrm{MAP}$ in blood, mediastinal draining lymph nodes, and spleen. The similar alteration of CTLA-4 expression on the surface of Treg cells was observed in same tissues (Figure 6). 


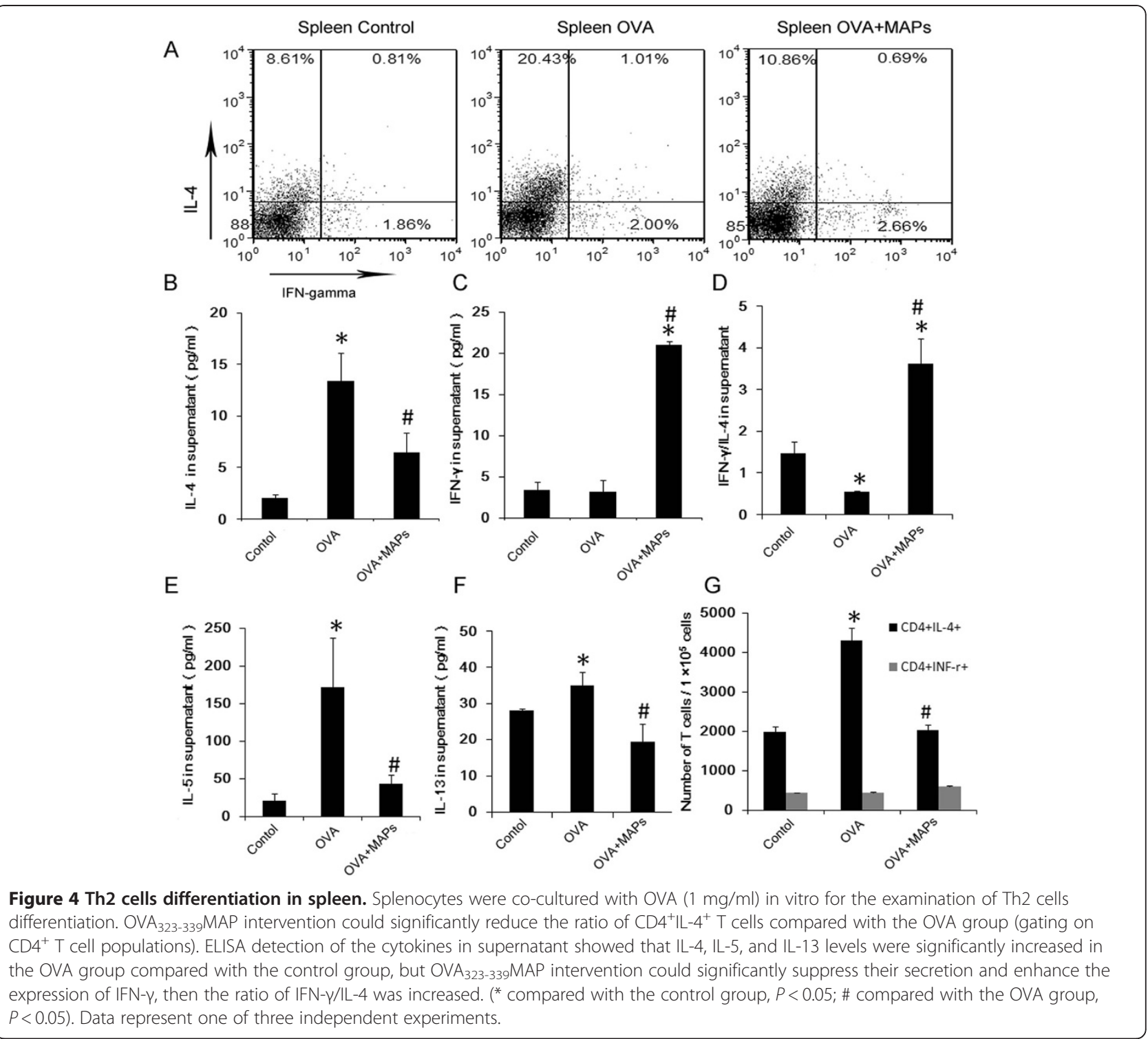

To further assess the function of Treg cells in these mice, we isolated $\mathrm{CD} 4{ }^{+} \mathrm{CD} 25^{+}$Treg cells from OVAchallenged mice, with or without $\mathrm{OVA}_{323-339} \mathrm{MAP}$ treatment. The Treg cells were co-cultured with effector $\mathrm{CD}_{4}^{+}$lymphocytes and $\mathrm{CD} 11 \mathrm{c}^{+}$antigen presenting cells (APCs) from the normal untreated mice. Five days later, effector $\mathrm{T}$ cells proliferation in response to in vitro OVA stimulation was assessed by FCM. The results showed that effector $\mathrm{T}$ cells underwent six proliferation cycles when they were cultured with Treg cells from OVA-challenged mice, the same as that of effector $\mathrm{T}$ cells without Treg. Despite OVA challenge, the Treg cells from the mice treated with $\mathrm{OVA}_{323-339} \mathrm{MAP}$ displayed a regulatory function, as evidenced by reduced effector $\mathrm{T}$ cell proliferation cycles (Figure 7).

\section{Discussion}

The OVA $_{323-339}$ peptides used in this experiment contained major $\mathrm{T}$ cell epitopes, representing major peptides that could be presented to Th cells through MHC class II molecules after APCs processing of OVA proteins. Structural analysis has confirmed that $\mathrm{OVA}_{323-339}$ peptides contain multiple loci that can be combined with MHC class II molecules and TCRs to form an immune sandwich complex and induce an immune response [27]. It has also been demonstrated that after $\mathrm{OVA}_{323-339}$ peptide challenge, $82 \%$ of OVA-sensitized mice developed immediate hypersensitivity. In addition, OVA and $\mathrm{OVA}_{323-339}$ peptides are equivalent in increasing mice airway reaction during challenge test [28]. Thus, $\mathrm{OVA}_{323-339}$ peptides have been considered for use in PIT in OVA-induced asthma in mice. However, Janssen et al.[15] found that after using 

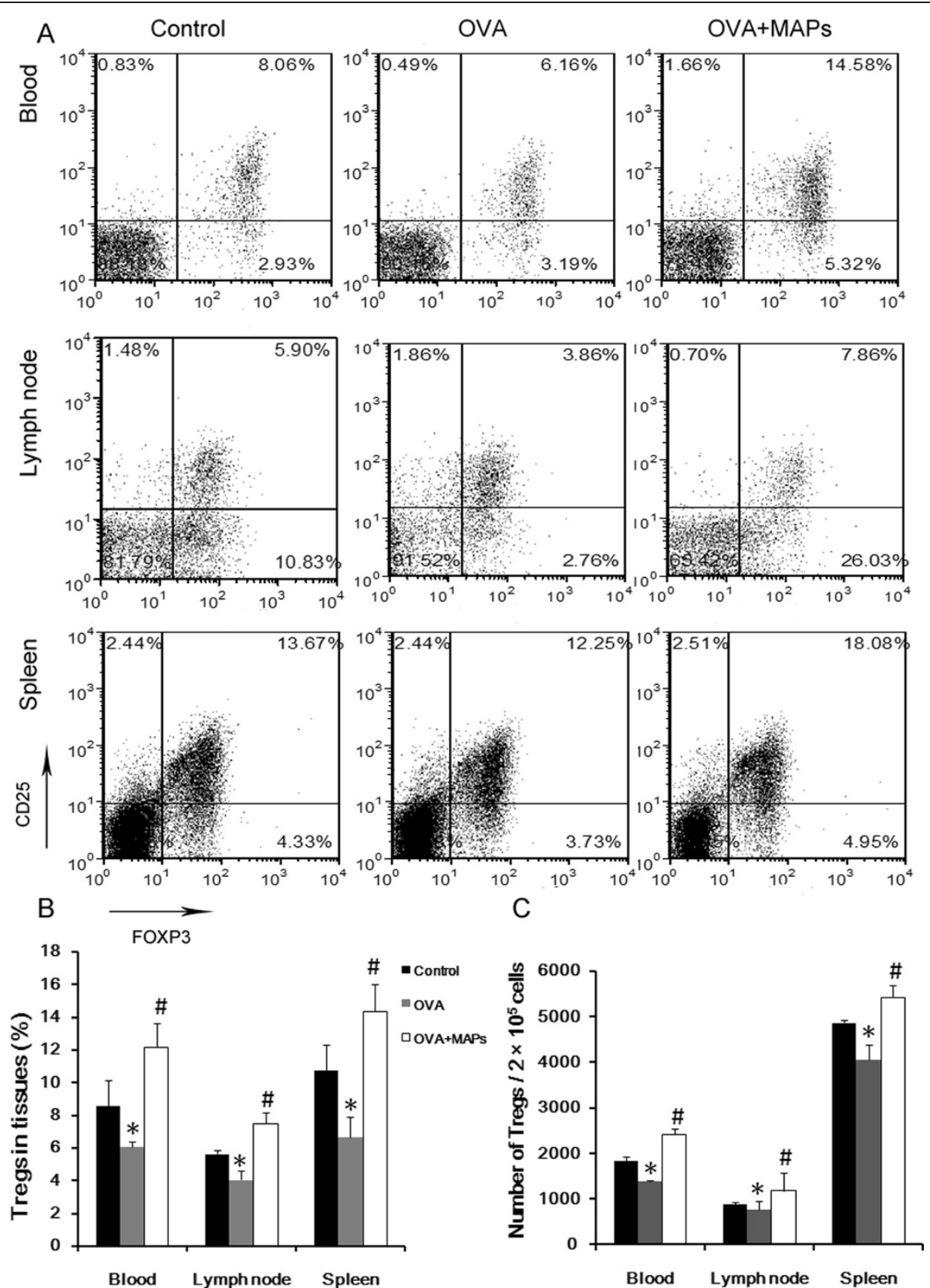

Figure $5 \mathrm{FCM}$ detection of $\mathrm{CD} 4^{+} \mathrm{CD} 25^{+} \mathrm{Foxp}^{+}$Treg cells in peripheral blood, mediastinal draining lymph nodes, and spleen of mice. In vivo OVA challenge could decrease the level of Treg cells in the mice. However, the levels of local and peripheral $C D 4^{+} C D 25^{+}$Foxp $3^{+}$Treg cells was about 0.5-1.0-fold increase after $\mathrm{OVA}_{323-339} \mathrm{MAP}$ treatment (gating on $\mathrm{CD}^{+}{ }^{+} \mathrm{T}$ cell populations, ${ }^{*}$ compared with the control group, $P<0.05$; \# compared with the OVA group, $P<0.05)$. Data represent one of three independent experiments.

these peptides for immunotherapy in mice, neither airway inflammation was alleviated nor were OVA-sIgE levels and Th2 immune responses suppressed, which are the opposite of the expected results. In our study, similar results were found using $\mathrm{OVA}_{323-339}$ peptide monomers, while after $\mathrm{OVA}_{323-339} \mathrm{MAP}$ intervention, airway inflammation in mice was significantly alleviated and EOS infiltration decreased markedly. These results suggest that
$\mathrm{OVA}_{323-339} \mathrm{MAP}$, instead of $\mathrm{OVA}_{323-339}$ peptide monomers have a significant antagonizing effect on airway inflammation. The previous reports confirmed that the branching lysine core is an immunologically silent dendrimeric structure [29], therefore, the effects of MAPs were not caused by the lysine core.

In addition, the effect of $\mathrm{OVA}_{323-339} \mathrm{MAP}$ on airway inflammation was dose-dependent. In clinical study, it 


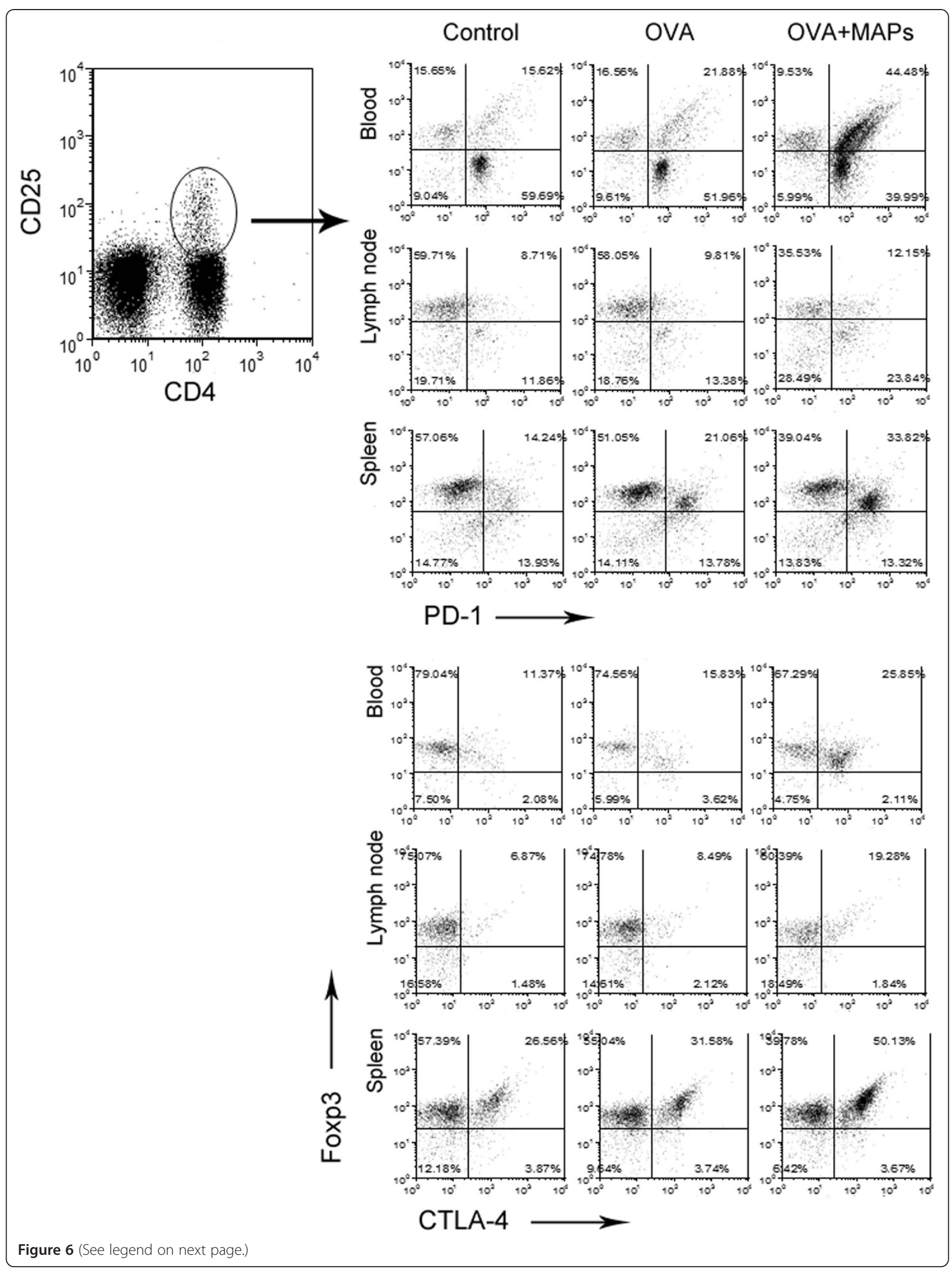


(See figure on previous page.)

Figure 6 FCM detection of PD-1 and CTLA-4 on the surface of CD4 ${ }^{+} \mathrm{CD} 25^{+}$Foxp $3^{+}$Treg cells in peripheral blood, mediastinal draining lymph nodes, and spleen of mice. To evaluate whether Treg cells in this study could play their role by contact inhibition, the surface expression of two major negative co-stimulatory molecules were detected by FCM. Freshly isolated cells from blood, mediastinal draining lymph nodes and spleen were stained with fluorescently antibodies for CD4, CD25, Foxp3 and PD-1 or CTLA-4. The results showed a significantly higher levels of PD-1 and CTLA-4 on the surface of Treg cells in MAPs treated mice than in control mice and OVA treated mice (gating on CD4 ${ }^{+}$CD25 $5^{+}$ cells).

has been suggested that a high-dose antigen can induce $\mathrm{T}$ cell unresponsiveness and also trigger apoptosis of Th2 cells in allergen stimulated periphery blood mononuclear cell (PBMC) from patients receiving SIT treatement [30-33]. Further analysis found that after MAPs intervention, the level of OVA-sIgE in periphery blood was significantly reduced, while OVA-sIgG 1 level was significantly increased. These results indicated that $\mathrm{OVA}_{323-339} \mathrm{MAP}$ intervention could affect the class-switch of OVA-specific immunoglobulin. Clinical trials have shown that allergen-sIgE level gradually decrease in allergic patients as a successful treatment proceeds, while the levels of sIgGs, especially $\operatorname{IgG}_{1}$ and $\operatorname{IgG}_{4}$ gradually increase $[34,35]$. Therefore, immunoglobulin class-switch is considered to be one of the important indicators reflecting the success of immunotherapy [36,37]. These results also showed that $\mathrm{OVA}_{323-339} \mathrm{MAP}$ could alter the immunological characteristics of monomer peptides after polymerization and possessed the opposite effect to peptide monomers. Wegman's study[16] also supported this conclusion. They found that PLP $139-151$ MAP instead of $\mathrm{PLP}_{139-151}$ peptide monomer applied for intervention in

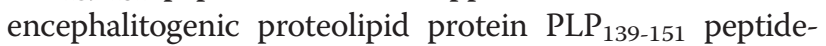
induced EAE mice could prevent antigen-specific $\mathrm{T}$ cells trafficking into the brain, thereby inhibiting inflammation. Our study showed that $\mathrm{OVA}_{323-339} \mathrm{MAP}$ suppressed Th2 immune response; reduced IL-4, IL-5, and IL-13 levels in either BALF or splenocyte culture supernatant significantly as well as the ratio of Th2 cells in spleen concurrently. Up-regulated ratio of IFN- $\gamma /$ IL-4 reflected that MAPs could affect the Th1/Th2 immune balance by inhibiting Th2 cell differentiation and Th2 immune responses.

It is well documented that Treg cells are essential for regulating immune effector cells, balancing Th1/Th2 response. They are a marker of tolerance induction in controlling autoimmune diseases and maintaining immune tolerance. $\mathrm{CD} 4{ }^{+} \mathrm{CD} 25^{+}$cells are a well characterized Treg population and possess potent immunosuppressive functions. Thus, we examined the quantity of Treg cells in our model. The results showed that $\mathrm{OVA}_{323-339} \mathrm{MAP}$ intervention significantly increased the ratio of $\mathrm{CD} 4^{+} \mathrm{CD} 25^{+} \mathrm{Foxp}^{+}$Treg cells in peripheral blood, mediastinal draining lymph nodes, and spleen of mice. Transcription factor Foxp3 is not only highly expressed in Treg cells, but also correlated with Treg activation. Thus, we further detected the level of transcription factor Foxp3 in the lung tissue by real-time PCR to evaluate the effect of Treg cells in lung tissue. The results indicated that the expression of Foxp3 is augmented significantly in MAPs treated mice. IL-10 is an anti-inflammatory cytokine produced by Treg cells. CD $4^{+} \mathrm{CD} 25^{+} \mathrm{Foxp} 3^{+}$Treg cells exert their anti-inflammatory effect through IL-10, which also promotes the conversion of $\mathrm{CD} 4^{+} \mathrm{CD} 25^{-}$Treg cells to $\mathrm{CD} 4{ }^{+} \mathrm{CD} 25^{+}$Treg cells. IL-10 suppresses $\mathrm{T}$ cells by blocking $\mathrm{CD} 2$, CD28, and inducible costimulatory molecule (ICOS) signals through a rapid signal transduction cascade, leading to T cell tolerance. IL-10 can also down-

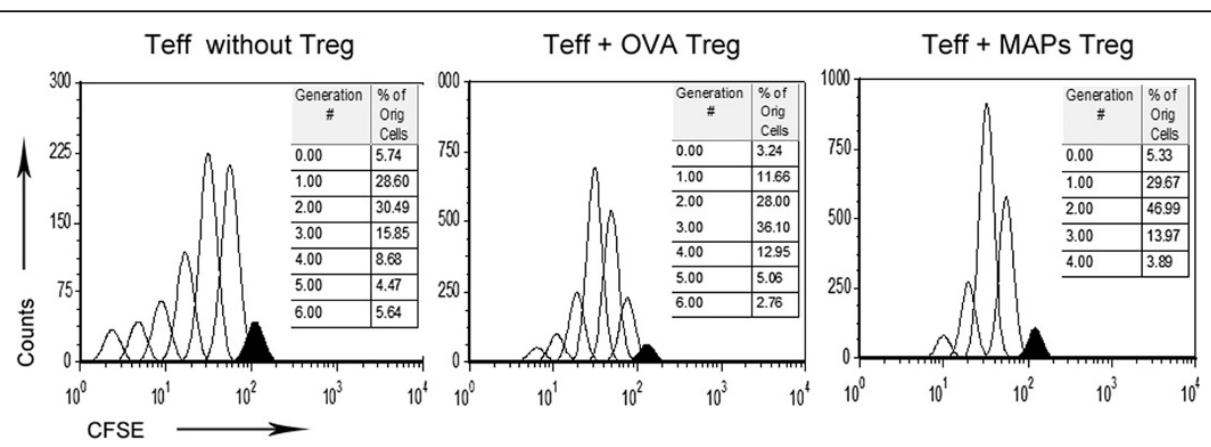

Figure 7 FCM detection of the inhibitory effect of Treg cells on Teff proliferation. $C D 4^{+} C D 25^{+} T$ cells from normal mice and OVAchallenged with or without intervention mice were isolated using immunomagnetic beads, then co-cultured with effector CD4 ${ }^{+}$lymphocytes and CD11 $\mathrm{c}^{+}$APC from normal mice for 5 days with OVA $(1 \mathrm{mg} / \mathrm{ml})$ stimulation. Effector T cells proliferation in response to OVA stimulation was assessed by FCM. The results showed that the proliferation cycles of Teff cells co-cultured with OVA $323-339$ MAP group were four cycles, less than that in the OVA group and Teff without Treg cells group (six cycles). Data represent one of three independent experiments. 
regulate the expression of MHC class II molecules and costimulatory molecules of monocytes and DCs, thus inhibiting the antigen-presenting function of these cells. In addition, IL-10 could also regulate the humoral immune response by promoting class-switch of immunoglobulin and up-regulating IgG production [38,39]. In the patients receiving PIT of bee venom or cat allergen, the IL-10 levels significantly increased $[13,40]$. For this reason, we further observed the changes of IL-10 levels in different groups. Our study showed that OVA $_{323-339}$ MAP could increase the IL-10 level in OVA challenge mice to a normal level, indicating that inducing IL-10 secretion may be one of the functions of $\mathrm{OVA}_{323-339} \mathrm{MAP}$. Besides its tolerance-inducing capability, peptide immunotherapy-induced IL-10-dependent immune tolerance correlates to inhibition of the "linkage epitope" response [41]. In our study, subcutaneous injection of $\mathrm{OVA}_{323-339} \mathrm{MAP}$ could alleviate airway inflammation development and Th2 immune response in mice challenged by the OVA protein, suggesting that $\mathrm{OVA}_{323-}$ ${ }_{339} \mathrm{MAP}$ therapy could inhibit in vivo immune response to the entire OVA protein.

It is acknowledged that TGF- $\beta 1$ could induce the conversion of naïve $\mathrm{CD} 4^{+} \mathrm{CD} 25^{-} \mathrm{T}$ cells into $\mathrm{CD} 4^{+} \mathrm{CD} 25^{+} \mathrm{T}$ cells by up-regulating Foxp3 expression, and play an important role in enhancing the immunosuppressive capacity of $\mathrm{CD} 4^{+} \mathrm{CD} 25^{+} \mathrm{T}$ cells $[42,43]$. Interestingly, the levels of TGF- $\beta 1$ in BALF of each group did not have marked differences, while TGF- $\beta 1$ transcription level in the lung of $\mathrm{OVA}_{323-339} \mathrm{MAP}$ group was increased when compared with the OVA group. The same phenomenon had been observed in our previous study, suggesting that membrane-bound TGF- $\beta 1$ in $\mathrm{CD} 44^{+} \mathrm{CD} 25^{+}$Treg cells was elevated [25]. Some reports have demonstrated that Treg cells could induce immune tolerance by cell-cell contacting directly with membrane-bound TGF- $\beta 1$ being essential for this regulation, and it also could mitigate allergic airway inflammation through a Notch1-mediated mechanism $[44,45]$. It has been reported that PD-1 and CTLA-4 contribute to the suppressive activity of allergen-specific regulatory cells, and are involved in the peripheral tolerance. Several studies have confirmed that PD-1 and its ligands (PD-L1 and PD-L2) as well as CTLA-4 and ligands (B7-1 and B7-2) could drive the differentiation of $\mathrm{CD}^{+}{ }^{+} \mathrm{Foxp}^{+}{ }^{+} \mathrm{T}$ cells, down-regulate contact hypersensitivity reaction, reduce airway hyperreactivity, prevent eosinophil infiltration in the lungs, and prevent IgE production [46-51]. Piconi et al. also found that during allergen-specific immunotherapy, the expression of PD-L1 is increased compared with untreated control group [52], which indirectly indicated that PD-1 played an important role in inducing immune tolerance. In our study, we found that the expression of PD- 1 and CTLA-4 on Treg cells in blood, mediastinal draining lymph nodes, and spleen did not alter noticeably between control and OVA groups, whereas $\mathrm{OVA}_{323-339} \mathrm{MAP}$ intervention significantly increased the expression of two molecules on the surface of Treg cells. It also indicated that $\mathrm{OVA}_{323-339} \mathrm{MAP}$ induced immune tolerance through cell-cell contacting suppression is mediated by membrane-bound TGF- $\beta 1$, as well as PD- 1 and CTLA-4.

As both cytokines and costimulatory molecules are key factors for Treg cells activity, we investigated the suppressive function of Treg cells. The function detection also showed that the inhibitory effect of Treg cell from the $\mathrm{OVA}_{323-339} \mathrm{MAP}$ intervention mice on effector $\mathrm{T}$ cells (Teff) proliferation was superior to that of OVA challenged mice. However, in clinical studies of PIT, there is still controversy over the role of Treg cells. After treatment with major $\mathrm{T}$ cell epitope of cat allergen Fel $\mathrm{d} 1$, the Th2 immune response was inhibited in vivo, but the inhibitory function of $\mathrm{CD} 4{ }^{+} \mathrm{CD} 25^{+}$Treg cells was not significantly enhanced [24]. In another study on Fel $\mathrm{d} 1$, after peptide treatment, a group of $\mathrm{CD} 4^{+} \mathrm{T}$ cells with a regulatory effect significantly increased and could inhibit $\mathrm{CD}^{-} \mathrm{T}$ cells function [23]. In addition, Wegman et al.[16] found that MAPs treatment did not have a clear effect on $\mathrm{CD}^{+}{ }^{+} \mathrm{Foxp}^{+}$cells in the mouse spleen and central nervous system. However, our research showed that $\mathrm{OVA}_{323-339} \mathrm{MAP}$ intervention could not only increase the quantity of Treg cells, but also enhance their function, accompanied by inversing Th1/Th2 balance, regulating humoral immunity, and alleviating mouse airway inflammation.

\section{Conclusions}

This study demonstrated that $\mathrm{OVA}_{323-339} \mathrm{MAP}$, being different from $\mathrm{OVA}_{323-339}$ peptide, could inhibit the Th2 immune response and alleviate allergic airway inflammation in mice model and this function may be mediated by Treg cells through direct and indirect mechanisms.

\section{Methods}

\section{Experimental materials}

In all experiments, 6 to 8 week-old female Balb/c mice (purchased from the Shanghai SLAC Laboratory Animal Co., Ltd.) were allocated randomly to either the experimental group or the control group after 1-week adaptive feeding under SPF conditions ( $n=6$ in each group). The animal experiment protocols were approved by the Ethics Committee of Ruijin Hospital Affiliated to Shanghai Jiao Tong University School of Medicine. OVA ${ }_{323-339}$ MAP octamers were kindly provided by Dr. Dave J Hinrichs at Portland VA Medical Center. OVA ${ }_{323-339}$ MAP is similar to PLP ${ }_{139-151}$ MAP as described by Wegman and Hinrichs [16], The MAP core is almost the same and the only difference between them is the sequence of the leading peptide. The amino acid sequence of the $\mathrm{OVA}_{323-339}$ peptide 
was Ile-Ser-Gln-Ala-Val-His-Ala-Ala-His-Ala-Glu-Ile-AsnGlu-Ala-Gly-Arg.

\section{Preparation of the animal model and intervention therapy}

Airway inflammation mouse model was constructed and the mice were interfered according to previous reports $[15,25,53]$. In brief, each mouse involved with airway inflammation (OVA group) received an intraperitoneal injection of $100 \mu \mathrm{g}$ OVA (V grade, Sigma, USA) in $0.2 \mathrm{ml}$ $\mathrm{Al}(\mathrm{OH})_{3}$ adjuvant suspension on day 0 and day 14 , respectively. Following the OVA injection on day 14, the mice were immediately intranasal challenged with $100 \mu \mathrm{g}$ of OVA in $50 \mu \mathrm{l}$ saline after anaesthetization via inhalation of isoflurane. The same treatment was conducted from day 32 to day 39, respectively. In the control group, mice received the same volume of $\mathrm{Al}(\mathrm{OH})_{3}$ to sensitize and saline to challenge. The intervention therapy was started on day 27 and repeated on day 30. In $\mathrm{OVA}_{323-339}$ group, $200 \mu \mathrm{g}$ of $\mathrm{OVA}_{323-339}$ peptide monomers (Anaspec, USA) in $200 \mu \mathrm{l}$ saline was injected subcutaneously into the back of mice. In the OVA 323 ${ }_{339}$ MAP group, a series concentration of $\mathrm{OVA}_{323-}$ ${ }_{339}$ MAP octamers $(57.2,114.4,171.8$ and $228.8 \mu \mathrm{g}$ of OVA $_{323-339}$ MAP equals to 50,100, 150 and $200 \mu \mathrm{g}$ of $\mathrm{OVA}_{323-339}$ peptides, respectively) was injected in the same way. The percentage of the lysine core matrix in total mass was about $12.6 \%$ [16]. The concentration series of $\mathrm{OVA}_{323-339} \mathrm{MAP}$ octamers were administrated to evaluate the dose-effects of $\mathrm{OVA}_{323-339}$ MAP in airway inflammation mice. For comparison, on the same day of treatment, equivalent volume of saline instead of the $\mathrm{OVA}_{323-339}$ peptide monomers or $\mathrm{OVA}_{323-339} \mathrm{MAP}$ octamers was subcutaneously injected in the control and OVA groups.

\section{Tissue harvest}

Twenty-four hour after the final challenge (day 40), all mice were anaesthetized with isoflurane and sacrificed after collecting blood via ophthalmic vein. For each mouse, the trachea was exposed by blunt dissection. Pre-cooled saline $(0.4 \mathrm{ml})$ was slowly injected into the trachea using a 22-gauge i.v. catheter for 3 times, the BALF was collected. This procedure recovered 80 to $90 \%$ of the infused fluid.

After collecting BALF, mediastinal lymph nodes, spleens, and lungs were collected. The right inferior lung was fixed in 10\% neutral formalin for 48 hours, embedded in paraffin, and sectioned $(4 \mu \mathrm{m})$ for hematoxylineosin (HE) staining to observe airway inflammation under the microscope (Olympus AX70, Japan). The left lung was also removed and homogenized for RNA extraction.

\section{Cell counts in BALF and analysis of peribronchial inflammation}

The collected BALF was centrifuged at $453 \mathrm{~g}$ at $4^{\circ} \mathrm{C}$ for 5 minutes. The supernatant was then stored at $-80^{\circ} \mathrm{C}$ before further study. The cell pellet was resuspended in $500 \mu \mathrm{l}$ saline and counted using a blood cell counting plate. A small amount of the cell suspension was fixed in $95 \%$ ethanol for 30 minutes for routine HE staining. A total of 200 cells were randomly selected to calculate EOS/NEU/MAC/LYM and their proportion under the microscope (Olympus AX70, Japan). Different cell counts were calculated by the following equation:

$\begin{aligned} \text { Total number }= & \left(\frac{\text { number of target cell under the microscope }}{200}\right) \\ & \times \text { total cell count }\end{aligned}$

The severity of peribronchial inflammation was graded semiquantitatively according to the published reference [54] for the following features: 0: normal; 1: few cells; 2 : a ring of inflammatory cells, 1 cell layer deep; 3: a ring of inflammatory cells, 2-4 cells deep; 4: a ring of inflammatory cells of 4 cells deep.

\section{Cell culture}

The single cell suspensions from the mediastinal lymph nodes and spleens were prepared under sterile conditions. Then RPMI-1640 complete culture medium (containing $10 \%$ fetal bovine serum, 1\% penicillin/ streptomycin, 0.1\% 2-mercaptoethanol, Gibco, USA) was added to adjust cell concentration to $5 \times 10^{6} / \mathrm{ml}$ and these cells were seeded into a 24-well cell culture plate (Corning, USA). The cells were then stimulated with $1 \mathrm{mg} / \mathrm{ml}$ OVA and incubated in the $\mathrm{CO}_{2}$ incubator with $5 \% \mathrm{CO}_{2}$ and $95 \%$ humidity at $37^{\circ} \mathrm{C}$. Five days later, all wells were replaced with $1 \mathrm{ml}$ fresh RPMI-1640 complete culture medium without OVA, and cultivated overnight under the same culture condition. Six hours before cells collection, $50 \mathrm{ng} / \mathrm{ml}$ phorbol myristoyl acetate (PMA, Sigma, USA), $1 \mu \mathrm{g} / \mathrm{ml}$ ionomycin (Sigma, USA) and 1:1000 Brefeldin A (BFA, eBioscience, USA) were added into each well to stimulate the cytokines secretion. The primary culture supernatant was obtained for cytokines detection and the cells were collected and rinsed in PBS for FCM analysis.

\section{ELISA}

For the detection of OVA-sIgE, a 96-well ELISA plate (Corning, USA) was coated with $100 \mu \mathrm{l}$ coating buffer (0.1 mol/L carbonate buffer, $\mathrm{pH}$ 9.5) containing OVA $(10 \mu \mathrm{g} / \mathrm{ml})$, and then sealed and stored at $4^{\circ} \mathrm{C}$ overnight. The plate was then washed three times with Phosphate Buffered Saline (PBS) containing 0.05\% Tween20 (PBS/T), blocked with $200 \mu$ l blocking buffer (PBS containing 10\% 
BSA), and incubated for 2 hours. After washing the plate, $100 \mu \mathrm{l}$ of each serum sample (diluted at 1:100) or mouse OVA sIgE standards (Serotec, UK) were added in the well. The standard was diluted into a final concentration series of 10000, 5000, 2500, 1250, 625, 312.5, 156.3 and $19.5 \mathrm{ng} / \mathrm{ml}$, respectively. The plate was incubated at $37^{\circ} \mathrm{C}$ for 2 hours. After rinsing with PBS, $100 \mu \mathrm{l}$ of horseradish peroxidase (HRP)-goat anti-mouse IgE antibody (Serotec, UK, 1:5000) were added into each well, and incubated at $37^{\circ} \mathrm{C}$ for additional 2 hours and rinsed for detection.

For the detection of OVA-sIgG, a 96-well ELISA plate was coated with $100 \mu \mathrm{l}$ of coating buffer containing rabbit anti-mouse IgG $(\mathrm{H}+\mathrm{L})$ (SouthernBiotech, USA, 1:8000) for each standard curve well and $100 \mu \mathrm{l}$ coating buffer containing OVA $(1 \mu \mathrm{g} / \mathrm{ml})$ for each sample well. The plate was incubated at $4^{\circ} \mathrm{C}$ overnight, washed with $\mathrm{PBS} / \mathrm{T}$ three times, and then blocked for 2 hours at room temperature. After rinsing, $100 \mu \mathrm{l}$ mouse IgG1 standards (Southern Biotech, USA) of the dilution concentrations 1000, 200, 40, 8, 1.6, 0.32 and $0.16 \mathrm{ng} / \mathrm{ml}$ were added to the standard curve wells and $100 \mu \mathrm{l}$ serum sample (1:500) were added into the OVA coated wells. The plate was incubated at room temperature for 2 hours and rinsed with PBS/T. Finally, $100 \mu \mathrm{l}$ of HRP-goat anti-mouse IgG1 antibody (1:32000, SouthernBioetch, USA) were added and incubated at room temperature for 2 hours and rinsed for analysis.

For detection, $100 \mu \mathrm{l}$ of tetramethyl benzidine dihydrochloride (TMB) chromogenic reagent was added to each well, and the plate was incubated at room temperature for 15 minutes before $100 \mu \mathrm{H}_{2} \mathrm{SO}_{4}(1 \mathrm{~mol} / \mathrm{L})$ was added to terminate the reactions. The absorbance was determined at $450 \mathrm{~nm}$ wavelength and the concentration of OVA-sIgE or OVA-sIgG of each sample was calculated based on the standard curve.

The levels of IL-4, IFN- $\gamma$, IL-5, IL-13, IL-10, and TGF- $\beta 1$ in BALF or cell culture supernatant were determined using ELISA kits according to the manufacturer's instructions (Biolegend, USA or eBioscience, USA).

\section{Real-time PCR}

After collecting BALF, the mice left lung was removed and homogenized, total RNA was extracted by Trizol (Invitrogen Life Technologies). cDNA samples were obtained by PrimeScript reverse transcriptase (Takara, Japan). Real-time PCR was performed using an ABI Prism 7900HT (Applied Biosysterms, Foster Ctiy, CA) according to the manufacturer's instructions. Primer sequences specific for $\beta$-actin is forward primer 5'-CTA AGG CCA ACC GTG AAA AG-3' and reverse primer 5'-AGC CTG GAT GGC TAC GTA CAT-3'. Primer sequences specific for IL-10 is forward primer 5'AGA AGC ATG GCC CAG AAA TCA-3' and reverse primer 5'-GGC CTT GTA GAC ACC TTG GT-3'. Primer sequences specific for TGF- $\beta 1$ is forward primer 5'-ATC CTG TCC AAA CTA AGG CTC G-3' and reverse primer 5'-ACC TCT TTA GCA TAG TAG TCC GC-3'. Primer sequences specific for Foxp3 is forward primer 5'-CCC AGG AAA GAC AGC AAC CTT-3' and reverse primer 5'-TTC TCC AAC CAG GCC ACT TG-3'. All primers were designed and synthesized by Invitrogen Corporation. Reaction conditions were 2 minutes at $50^{\circ} \mathrm{C}$, 10 minutes at $95^{\circ} \mathrm{C}$, followed by 40 cycles of $95^{\circ} \mathrm{C}$ for 15 seconds and $60^{\circ} \mathrm{C}$ for 1 minute, finally, $50^{\circ} \mathrm{C}$ for 15 seconds, $60^{\circ} \mathrm{C}$ for 15 seconds and $95^{\circ} \mathrm{C}$ for 10 minutes.

\section{Flow cytometry}

One hundred microlitre heparinized peripheral blood were obtained and red blood cells were lysed to prepare the single cell suspension. All cultured cells from peripheral blood, mediastinal lymph nodes or spleen were harvested, the surface staining antibodies were FITC-anti-CD4, APC-anti-CD25, PE-anti-PD-1 or PECY-7-anti-CTLA-4 and the intracellular staining antibodies were PE-anti-IL-4, APC-anti-IFN- $\gamma$, PE-anti-Foxp3 or PECY-7-anti-Foxp3, together with isotype control staining. Meanwhile, after staining, the cells were washed with PBS and fixed in 1\% paraformaldehyde to count Th1, Th2 and $\mathrm{CD} 4{ }^{+} \mathrm{CD} 25^{+} \mathrm{Foxp}^{+}$Treg cells, as well as the expression of PD-1 and CTLA-4 on the surface of Treg cells. All antibodies were purchased from eBioscience Company and procedures were carried out according to the manufacturer's instructions.

Immunomagnetic beads (Miltenyibiotec, USA) were used to screen out spleenic $\mathrm{CD} 4^{+} \mathrm{CD} 25^{+} \mathrm{T}$ cells from mice in each group, as well as $\mathrm{CD} 11 \mathrm{c}^{+}$cells from mice in the control group, according to the manufacturer's instructions. $\mathrm{CD} 4^{+} \mathrm{CD} 25^{-} \mathrm{T}$ cells in the control group mice were collected as Teff, which were marked with carboxyfluorescein succinimidyl ester (CFSE; eBioscience, USA). CD $11 \mathrm{c}^{+}$cells $\left(2 \times 10^{4}\right)$ and $\mathrm{CD} 4^{+} \mathrm{CD} 25^{+} \mathrm{T}$ cells $\left(1 \times 10^{5}\right)$, as well as CFSE-Teff $\left(1 \times 10^{5}\right)$, were seeded into 96 -well round bottom plates (Corning, USA), co-cultured with $1 \mathrm{mg} / \mathrm{ml} \mathrm{OVA}$ in the incubator at $37^{\circ} \mathrm{C}$, with $5 \% \mathrm{CO}_{2}$ and 95\% humidity. After 5 days of cultivation, cells were collected and stained with PE-anti-CD4, rinsed in PBS, and fixed in $1 \%$ paraformaldehyde.

All stained cells were detected using the FACScan Flow Analyzer and data were analyzed using FACS express $\mathrm{v}$ 3.0 software.

\section{Statistical analysis}

Data were presented as mean \pm standard deviation and analyzed using SPSS16.0 software. Statistical comparisons were made by One-Way ANOVA analysis in Figures 2, 3, 4 and 5. 


\section{Abbreviations}

SIT, specific immunotherapy; PIT, peptide immunotherapy; MAP, multiple antigen peptide; OVA, ovalbumin; Treg, T regulatory cell; BALF, bronchial alveolar lavage fluid; slgE, specific immunoglobulin E; slgG, specific immunoglobulin G; EAE, encephalomyelitis; PBMC, periphery blood mononuclear cell; ICOS, inducible costimulatory molecule; PD-

1, programmed death-1; CTLA-4, cytotoxic T lymphocyte associated antigen 4; HE, hematoxylin-eosin; EOS, eosinophils; NEU, neutrophil;

LYM, lymphocytes; MAC, macrophages; PMA, phorbol myristoyl acetate; BFA, brefeldin A; FCM, flow cytometry; CFSE, carboxyfluorescein succinimidyl ester; TGF, transforming growth factor; APCs, antigen presenting cells; HRP, horseradish peroxidase; PBS, phosphate buffered saline; $T M B$, tetramethyl benzidine dihydrochloride.

\section{Competing interests}

The authors declare that they have no competing interests.

\section{Authors' contributions}

WS and WZ contributed equally to this work. WS conceived of and carried out most of the experiments, WZ conceived of the experiments and performed quantitative PCR, YJZ conducted statistical analyses. All authors discussed the results. ZX designed and directed the project.

\section{Acknowledgements}

We thank Dr. Eugen Khan and Dr. Chengbiao Wu at UCSD for critical review of the manuscript.

This work was supported by grants from the National Natural Science Foundation of China (Grants 30871022, 81070022 and 81128001), Shanghai Municipal Science and Technology Commission Foundation (10410701000).

Received: 19 January 2012 Accepted: 27 June 2012

Published: 6 July 2012

\section{References}

1. Larche M: Peptide immunotherapy for allergic diseases. Allergy 2007, 62:325-331.

2. Pipet $A$, Botturi $K$, Pinot $D$, Vervloet $D$, Magnan A: Allergen-specific immunotherapy in allergic rhinitis and asthma. Mechanisms and proof of efficacy. Respir Med 2009, 103:800-812.

3. Durham SR, Walker SM, Varga EM, Jacobson MR, O'Brien F, Noble W, Till S., Hamid QA, Nouri-Aria KT: Long-term clinical efficacy of grass-pollen immunotherapy. N Engl J Med 1999, 341:468-475.

4. Briner TJ, Kuo MC, Keating KM, Rogers BL, Greenstein JL: Peripheral T-cell tolerance induced in naive and primed mice by subcutaneous injection of peptides from the major cat allergen Fel d I. Proc Natl Acad Sci U S A 1993, 90:7608-7612.

5. Hoyne GF, O'Hehir RE, Wraith DC, Thomas WR, Lamb JR: Inhibition of T cell and antibody responses to house dust mite allergen by inhalation of the dominant T cell epitope in naive and sensitized mice. J Exp Med 1993, 178:1783-1788.

6. Bauer L, Bohle B, Jahn-Schmid B, Wiedermann U, Daser A, Renz H, Kraft D, Ebner $C$ : Modulation of the allergic immune response in $B A L B / C$ mice by subcutaneous injection of high doses of the dominant $T$ cell epitope from the major birch pollen allergen Bet v 1. Clin Exp Immunol 1997, 107:536-541.

7. King TP, Lu G, Agosto H: Antibody responses to bee melittin (Api $m$ 4) and hornet antigen 5 (Dol $\mathrm{m} 5$ ) in mice treated with the dominant T-cell epitope peptides. J Allergy Clin Immunol 1998, 101:397-403.

8. Norman PS, Ohman JL Jr, Long AA, Creticos PS, Gefter MA, Shaked Z, Wood RA, Eggleston PA, Hafner KB, Rao P, et al: Treatment of cat allergy with T-cell reactive peptides. Am J Respir Crit Care Med 1996, 154:1623-1628.

9. Pene J, Desroches A, Paradis L, Lebel B, Farce M, Nicodemus CF, Yssel H, Bousquet J: Immunotherapy with Fel d 1 peptides decreases IL-4 release by peripheral blood T cells of patients allergic to cats. $J$ Allergy Clin Immunol 1998, 102:571-578.

10. Oldfield WL, Kay AB, Larche M: Allergen-derived T cell peptide-induced late asthmatic reactions precede the induction of antigen-specific hyporesponsiveness in atopic allergic asthmatic subjects. J Immunol 2001, 167:1734-1739.
11. Oldfield WL, Larche M, Kay AB: Effect of T-cell peptides derived from Fel d 1 on allergic reactions and cytokine production in patients sensitive to cats: a randomised controlled trial. Lancet 2002, 360:47-53.

12. Alexander C, Ying S, Ying S, B Kay A, Larche M: Fel d 1-derived T cell peptide therapy induces recruitment of CD4+ CD25+; CD4+ interferongamma $+T$ helper type 1 cells to sites of allergen-induced late-phase skin reactions in cat-allergic subjects. Clin Exp Allergy: J British Soc Allergy Clin Immunol 2005, 35:52-58.

13. Worm M, Lee HH, Kleine-Tebbe J, Hafner RP, Laidler P, Healey D, Buhot C, Verhoef A, Maillere B, Kay AB, et al: Development and preliminary clinical evaluation of a peptide immunotherapy vaccine for cat allergy. J Allergy Clin Immunol 2011, 127:89-97. 97 e81-14.

14. Alexander C, Tarzi M, Larche M, Kay AB: The effect of Fel d 1-derived T-cell peptides on upper and lower airway outcome measurements in catallergic subjects. Allergy 2005, 60:1269-1274.

15. Janssen EM, Wauben MH, Jonker EH, Hofman G, Van Eden W, Nijkamp FP, Van Oosterhout AJ: Opposite effects of immunotherapy with ovalbumin and the immunodominant T-cell epitope on airway eosinophilia and hyperresponsiveness in a murine model of allergic asthma. Am J Respir Cell Mol Biol 1999, 21:21-29.

16. Wegmann KW, Wagner CR, Whitham RH, Hinrichs DJ: Synthetic Peptide dendrimers block the development and expression of experimental allergic encephalomyelitis. J Immunol 2008, 181:3301-3309.

17. Mahajan B, Berzofsky JA, Boykins RA, Majam V, Zheng H, Chattopadhyay R, de la Vega P, Moch JK, Haynes JD, Belyakov IM, et al: Multiple antigen peptide vaccines against Plasmodium falciparum malaria. Infect Immun 2010, 78:4613-4624.

18. Zhao G, Sun S, Du L, Xiao W, Ru Z, Kou Z, Guo Y, Yu H, Jiang S, Lone Y, et al: An H5N1 M2e-based multiple antigenic peptide vaccine confers heterosubtypic protection from lethal infection with pandemic 2009 H1N1 virus. Virol J 2010, 7:151.

19. Haro I, Perez S, Garcia M, Chan WC, Ercilla G: Liposome entrapment and immunogenic studies of a synthetic lipophilic multiple antigenic peptide bearing VP1 and VP3 domains of the hepatitis A virus: a robust method for vaccine design. FEBS Lett 2003, 540:133-140.

20. Mozdzanowska K, Feng J, Eid M, Kragol G, Cudic M, Otvos L Jr, Gerhard W: Induction of influenza type A virus-specific resistance by immunization of mice with a synthetic multiple antigenic peptide vaccine that contains ectodomains of matrix protein 2. Vaccine 2003, 21:2616-2626

21. Franke ED, Sette A, Sacci I Jr, Southwood S, Corradin G, Hoffman SL: A subdominant CD8(+) cytotoxic T lymphocyte (CTL) epitope from the Plasmodium yoelii circumsporozoite protein induces CTLs that eliminate infected hepatocytes from culture. Infect Immun 2000, 68:3403-3411.

22. Kawamura KS, Su RC, Nguyen LT, Elford AR, Ohashi PS, Gariepy J: In vivo generation of cytotoxic $T$ cells from epitopes displayed on peptidebased delivery vehicles. I Immunol 2002, 168:5709-5715.

23. Verhoef A, Alexander C, Kay AB, Larche M: T cell epitope immunotherapy induces a CD4+ T cell population with regulatory activity. PLOS Med 2005, 2:e78.

24. Smith TR, Alexander C, Kay AB, Larche M, Robinson DS: Cat allergen peptide immunotherapy reduces $\mathrm{CD} 4(+) \mathrm{T}$ cell responses to cat allergen but does not alter suppression by CD4(+) CD25(+) T cells: a double-blind placebo-controlled study. Allergy 2004, 59:1097-1101.

25. Xia ZW, Xu LQ, Zhong WW, Wei JJ, Li NL, Shao J, Li YZ, Yu SC, Zhang ZL: Heme Oxygenase-1 Attenuates Ovalbumin-Induced Airway Inflammation by Up-Regulation of Foxp3 T-Regulatory Cells, Interleukin-10, and Membrane-Bound Transforming Growth Factor- 1. Am J Pathol 2007, 171:1904-1914.

26. Xia ZW, Zhong WW, Xu LQ, Sun JL, Shen QX, Wang JG, Shao J, Li YZ, Yu SC: Heme oxygenase-1-mediated CD4 + CD25high regulatory T cells suppress allergic airway inflammation. J Immunol 2006, 177:5936-5945.

27. Robertson JM, Jensen PE, Evavold BD: DO11.10 and OT-II T cells recognize a C-terminal ovalbumin 323-339 epitope. J Immunol 2000, 164:4706-4712.

28. Renz H, Bradley K, Larsen GL, McCall C, Gelfand EW: Comparison of the allergenicity of ovalbumin and ovalbumin peptide 323-339. Differential expansion of V beta-expressing T cell populations. J Immunol 1993, 151:7206-7213.

29. Tam JP: Recent advances in multiple antigen peptides. J Immunol Methods 1996, 196:17-32.

30. Rolland J, O'Hehir R: Immunotherapy of allergy: anergy, deletion, and immune deviation. Curr Opin Immunol 1998, 10:640-645. 
31. Gardner LM, O'Hehir RE, Rolland JM: High dose allergen stimulation of $T$ cells from house dust mite-allergic subjects induces expansion of IFNgamma + T Cells, apoptosis of CD4 + IL-4+ T cells and T cell anergy. Int Arch Allergy Immunol 2004, 133:1-13.

32. Antunez C, Mayorga C, Corzo JL, Jurado A, Torres MJ: Two year follow-up of immunological response in mite-allergic children treated with sublingual immunotherapy. Comparison with subcutaneous administration. Pediatr Allergy Immunol: official publication of the Eur Soc Pediatr Allergy Immunol 2008, 19:210-218.

33. Akdis CA, Blesken T, Akdis M, Wuthrich B, Blaser K: Role of interleukin 10 in specific immunotherapy. J Clin Invest 1998, 102:98-106.

34. Jutel $M$, Jaeger $L$, Suck $R$, Meyer $H$, Fiebig $H$, Cromwell $O$ : Allergen-specific immunotherapy with recombinant grass pollen allergens. J Allergy Clin Immunol 2005, 116:608-613.

35. Reisinger J, Horak F, Pauli G, van Hage M, Cromwell O, Konig F, Valenta R, Niederberger $V$ : Allergen-specific nasal IgG antibodies induced by vaccination with genetically modified allergens are associated with reduced nasal allergen sensitivity. J Allergy Clin Immunol 2005, 116:347-354.

36. Golden DB, Meyers DA, Kagey-Sobotka A, Valentine MD, Lichtenstein LM: Clinical relevance of the venom-specific immunoglobulin $\mathrm{G}$ antibody level during immunotherapy. J Allergy Clin Immunol 1982, 69:489-493.

37. Muller U, Helbling A, Bischof M: Predictive value of venom-specific lgE, IgG and lgG subclass antibodies in patients on immunotherapy with honey bee venom. Allergy 1989, 44:412-418.

38. Taylor A, Akdis M, Joss A, Akkoc T, Wenig R, Colonna M, Daigle I, Flory E, Blaser K, Akdis CA: IL-10 inhibits CD28 and ICOS costimulations of T cells via src homology 2 domain-containing protein tyrosine phosphatase 1 . J Allergy Clin Immunol 2007, 120:76-83.

39. Akdis CA, Akdis M: Mechanisms and treatment of allergic disease in the big picture of regulatory T cells. J Allergy Clin Immunol 2009, 123:735-746. quiz 747-738.

40. Tarzi M, Klunker S, Texier C, Verhoef A, Stapel SO, Akdis CA, Maillere B, Kay $A B$, Larche $M$ : Induction of interleukin-10 and suppressor of cytokine signalling-3 gene expression following peptide immunotherapy. Clin Exp Allergy: J British Soc Allergy Clin Immunol 2006, 36:465-474.

41. Campbell JD, Buckland KF, McMillan SJ, Kearley J, Oldfield WL, Stern LJ, Gronlund H, van Hage M, Reynolds CJ, Boyton RJ, et al: Peptide immunotherapy in allergic asthma generates IL-10-dependent immunological tolerance associated with linked epitope suppression. J Exp Med 2009, 206:1535-1547.

42. Chen W, Jin W, Hardegen N, Lei KJ, Li L, Marinos N, McGrady G, Wahl SM: Conversion of peripheral CD4 + CD25- naive T cells to CD4 + CD25+ regulatory T cells by TGF-beta induction of transcription factor Foxp3. $J$ Exp Med 2003, 198:1875-1886.

43. Huber S, Schramm C, Lehr HA, Mann A, Schmitt S, Becker C, Protschka M, Galle PR, Neurath MF, Blessing M: Cutting edge: TGF-beta signaling is required for the in vivo expansion and immunosuppressive capacity of regulatory CD4 + CD25+ T cells. J Immunol 2004, 173:6526-6531.

44. Ostroukhova M, Seguin-Devaux C, Oriss TB, Dixon-McCarthy B, Yang L, Ameredes BT, Corcoran TE, Ray A: Tolerance induced by inhaled antigen involves CD4(+) T cells expressing membrane-bound TGF-beta and FOXP3. J Clin Invest 2004, 114:28-38.

45. Ostroukhova M, Qi Z, Oriss TB, Dixon-McCarthy B, Ray P, Ray A: Tregmediated immunosuppression involves activation of the Notch-HES 1 axis by membrane-bound TGF-beta. J Clin Invest 2006, 116:996-1004.

46. Takahashi T, Tagami T, Yamazaki S, Uede T, Shimizu J, Sakaguchi N, Mak TW, Sakaguchi S: Immunologic self-tolerance maintained by CD25(+)CD4(+) regulatory $T$ cells constitutively expressing cytotoxic $T$ lymphocyteassociated antigen 4. J Exp Med 2000, 192:303-310.

47. Tivol EA, Borriello F, Schweitzer AN, Lynch WP, Bluestone JA, Sharpe AH: Loss of CTLA-4 leads to massive lymphoproliferation and fatal multiorgan tissue destruction, revealing a critical negative regulatory role of CTLA-4. Immunity 1995, 3:541-547.

48. Radhakrishnan S, lijima K, Kobayashi T, Rodriguez M, Kita H, Pease LR: Blockade of allergic airway inflammation following systemic treatment with a B7-dendritic cell (PD-L2) cross-linking human antibody. J Immunol 2004, 173:1360-1365.

49. Oflazoglu E, Swart DA, Anders-Bartholo P, Jessup HK, Norment AM, Lawrence WA, Brasel K, Tocker JE, Horan T, Welcher AA, et al: Paradoxical role of programmed death-1 ligand 2 in Th2 immune responses in vitro and in a mouse asthma model in vivo. Eur J Immunol 2004, 34:3326-3336.

50. Mann-Chandler MN, Kashyap M, Wright HV, Norozian F, Barnstein BO, Gingras S, Parganas E, Ryan JJ: IFN-gamma induces apoptosis in developing mast cells. J Immunol 2005, 175:3000-3005.

51. Kim HK, Guan H, Zu G, Li H, Wu L, Feng X, Elmets C, Fu Y, Xu H: High-level expression of $\mathrm{B} 7-\mathrm{H} 1$ molecules by dendritic cells suppresses the function of activated T cells and desensitizes allergen-primed animals. J Leukoc Biol 2006, 79:686-695.

52. Piconi S, Trabattoni D, Saresella M, lemoli E, Schenal M, Fusi A, Borelli M, Chen L, Mascheri A, Clerici M: Effects of specific immunotherapy on the B7 family of costimulatory molecules in allergic inflammation. J Immunol 2007, 178:1931-1937.

53. Vargaftig $B B$, Singer M: Leukotrienes mediate part of Ova-induced lung effects in mice via EGFR. Am J Physiol Lung Cell Mol Physiol 2003, 285:L808-L818.

54. Myou S, Leff AR, Myo S, Boetticher E, Tong J, Meliton AY, Liu J, Munoz NM, Zhu X: Blockade of inflammation and airway hyperresponsiveness in immune-sensitized mice by dominant-negative phosphoinositide 3kinase-TAT. J Exp Med 2003, 198:1573-1582.

doi:10.1186/1471-2172-13-34

Cite this article as: Su et al: Synthesized OVA $323-339$ MAP octamers mitigate OVA-induced airway inflammation by regulating Foxp3 $\mathrm{T}$ regulatory cells. BMC Immunology 2012 13:34.

\section{Submit your next manuscript to BioMed Central and take full advantage of:}

- Convenient online submission

- Thorough peer review

- No space constraints or color figure charges

- Immediate publication on acceptance

- Inclusion in PubMed, CAS, Scopus and Google Scholar

- Research which is freely available for redistribution 